\title{
Respiratory symptoms in elderly Chinese living in Hong Kong
}

\author{
C.K.W. Lai*, S.C. Ho**, J. Lau+, Y.K. Yuen*, S.S. Ho*, C.H.S Chan*, J. Woo*
}

Respiratory symptoms in elderly Chinese living in Hong Kong. C.K.W. Lai, S.C. Ho, J. Lau, Y.K. Yuen, S.S. Ho, C.H.S Chan, J. Woo. @ERS Journals Ltd 1995.

ABSTRACT: Respiratory diseases can cause considerable disability in the elderly because of their limited respiratory reserve as a result of ageing. We have investigated the prevalence of respiratory symptoms and diseases in elderly Chinese in Hong Kong and compared these data with those in elderly Caucasian populations.

Two thousand and thirty two (999 male and 1,033 female) subjects, selected by age-stratified random sampling from a register of Hong Kong residents aged 70 yrs and over were interviewed to complete a respiratory questionnaire. Total serum immunoglobulin $E$ (IgE) was measured in 195 subjects.

At least one respiratory symptom was reported by $56 \%$ of subjects. The most frequently reported symptoms were morning phlegm (26\%), chronic cough with phlegm $(10 \%)$ and wheeze in the past 12 months $(8 \%)$. Of the self-reported diseases, the commonest was chronic bronchitis $(7 \%)$, followed by asthma $(5 \%)$, pulmonary tuberculosis (3\%) and emphysema (2\%). Of the 218 subjects with obstructive airway diseases, $128(59 \%)$ had sought medical advice in the past 12 months. The most important determinants for respiratory symptoms and diseases were smoking and social class. Total serum IgE was significantly higher in current smokers than nonsmokers and also in those with chronic cough and phlegm than those without these complaints.

Our study shows that respiratory ailments in Hong Kong elderly are as common as those reported in Sweden and the USA but less than those in England.

Eur Respir J., 1995, 8, 2055-2061.
Depts of*Medicine, **Community Medicine, and ${ }^{+}$Centre for Clinical Trials and Epidemiological Research, Chinese University of Hong Kong, Hong Kong.

\section{Correspondence: C.Lai}

Dept of Medicine

Chinese University of Hong Kong,

Prince of Wales Hospital,

Shatin

N.T.

Hong Kong

Keywords: Asthma Chinese

chronic bronchitis elderly

respiratorysymptoms

Received: November 211994

Accepted after revision September 251995

Supported by the Croucher Foundation (163403000 and 165107000), Hong Kong.
Respiratory complaints are common in the general population and are one of the major causes of morbidity and mortality on a worldwide basis. Because of the ease of sampling, most of the epidemiological data on respiratory symptoms and diseases are obtained from studies in school children or the general population, with relatively little data available on elderly subjects. With a limited respiratory reserve as a result of ageing, it is not surprising that the elderly suffer considerable disability when afflicted by respiratory ailments, particularly chronic diseases, such as asthma or chronic obstructive airway disease $[1,2]$. More recently, two separate studies in southern England and one from northern Sweden have suggested that respiratory complaints are common in the elderly, with up to $60 \%$ of people aged $65 \mathrm{yrs}$ or older having at least one respiratory symptom [3-5]. However, little, if any, information is available in the oriental population, particularly Chinese. As the distribution of respiratory disease is strongly influenced by genetic and environmental factors, such as air pollution, tobacco consumption, allergens, etc., one would expect that its prevalence and severity will vary from one place to another.

In Hong Kong, the current life expectancy for men is $74 \mathrm{yrs}$ and for women is $79.8 \mathrm{yrs}$, comparable to those seen in Western countries. In 1991, about $8.8 \%$ of the population were over $64 \mathrm{yrs}$ of age. This figure is projected to rise to $11.6 \%$ by the year 2001 . Clearly, estimates of prevalence of respiratory symptoms and disease are important for formulating public health policies and also for planning the use of health services by the elderly as a result of these ailments.

In a recent health survey in a group of elderly Chinese in Hong Kong, selected by random sampling stratified by age and sex, we have determined the prevalence of respiratory symptoms and diseases and their relationship to population characteristics, and compared these data with those in elderly Caucasian populations.

\section{Subjects and methods}

During the period from July 1991 to July 1992, a health survey was carried out on 2,032 elderly Chinese, aged 70 yrs and over, selected by stratified random sampling from a registered list of all recipients of Old Age and Disability Allowances in Hong Kong. The Old Age Allowance list covers over $90 \%$ of those in the study age group, since eligibility is by age alone, independent of income. The Disability Allowance list covers those subjects who may be receiving additional social welfare support. Subjects were stratified by age and sex so that there would be 300 subjects in the 70-74 and 75-79 yrs 
age groups in each sex, and 150 subjects in the 80-84, 8589 and $\geq 90$ yrs age groups in each sex. A total of 3,400 letters were sent via the Social Welfare Department to these subjects to recruit the required numbers in each cell, and nonresponders were sent a second letter after 4 weeks. Approximately $60 \%$ of men and women participated in the survey. The response rate was higher among the older men aged 80 yrs and above (66\%), and slightly lower in women aged 70-79 yrs (53\%). A total of 2,032 subjects were interviewed (999 males and 1,033 females), of whom $16 \%$ lived in institutions.
Interviewers visited these subjects and a questionnaire on lung health was completed at their places of residence. This questionnaire was a Chinese translation of the one used by Dow et al. [3] in their survey of the elderly residing in southern England. It consisted of information on symptoms of wheeze, morning chest tightness, breathlessness, sputum production and cough, either occurring spontaneously or on exposure to common aero-allergens or irritants; past history of respiratory diseases including asthma, chronic bronchitis emphysema and tuberculosis, smoking habits and last full-time

Table 1. - Characteristics of subjects

\begin{tabular}{|c|c|c|c|c|c|c|c|}
\hline & \multicolumn{3}{|c|}{ Male } & \multicolumn{3}{|c|}{ Female } & \multirow[t]{2}{*}{ Total } \\
\hline & $70-79$ yrs & $80-89$ yrs & $\geq 90 \mathrm{yrs}$ & $70-79$ yrs & $80-89$ yrs & $\geq 90 \mathrm{yrs}$ & \\
\hline \multicolumn{8}{|l|}{ Smoking habits $n$} \\
\hline Nonsmokers & $164(8.1)$ & $98(4.9)$ & $40(1.9)$ & $424(21.0)$ & $223(11.0)$ & $116(5.7)$ & $1065(52.7)$ \\
\hline Ex-smokers & $264(13.1)$ & $134(6.6)$ & $44(2.2)$ & $88(4.4)$ & $66(3.3)$ & $26(1.3)$ & $622(30.8)$ \\
\hline Current smokers & $168(8.3)$ & $59(2.9)$ & $21(1.0)$ & $63(3.1)$ & $12(0.6)$ & $10(0.5)$ & $333(16.5)$ \\
\hline \multicolumn{8}{|l|}{ Social class $n$} \\
\hline Nonmanual & $197(9.8)$ & $82(4.1)$ & $21(1.0)$ & $99(4.9)$ & $36(1.8)$ & $12(0.6)$ & $447(22.2)$ \\
\hline Skilled manual & $204(10.1)$ & $111(5.5)$ & $45(2.2)$ & $220(10.9)$ & $159(7.9)$ & $75(3.7)$ & $814(40.4)$ \\
\hline $\begin{array}{l}\text { Unskilled/semi-skilled } \\
\text { and manual }\end{array}$ & $194(9.6)$ & $97(4.8)$ & $40(19.9)$ & $254(12.6)$ & $104(5.2)$ & $64(3.2)$ & $753(37.4)$ \\
\hline
\end{tabular}

The values in parentheses are percentages of total; the total numbers of subjects with information on smoking habits and social class were 2,020 and 2,014, respectively.

Table 2. - Prevalence of respiratory symptoms according to gender and age expressed as percentage of those who answered all of the questions

\begin{tabular}{|c|c|c|c|c|c|c|c|}
\hline \multirow[b]{2}{*}{ Symptom*/disease } & \multicolumn{3}{|c|}{ Male } & \multicolumn{3}{|c|}{ Female } & \multirow{2}{*}{$\begin{array}{c}\text { Total } \\
\%\end{array}$} \\
\hline & $\begin{array}{c}70-79 \text { yrs } \\
(\mathrm{n}=595) \\
\%\end{array}$ & $\begin{array}{c}80-89 \text { yrs } \\
(n=292) \\
\% \\
\end{array}$ & $\begin{array}{c}\geq 90 \text { yrs } \\
(n=110) \\
\%\end{array}$ & $\begin{array}{c}70-79 \text { yrs } \\
(\mathrm{n}=575) \\
\%\end{array}$ & $\begin{array}{c}80-89 \text { yrs } \\
(\mathrm{n}=299) \\
\%\end{array}$ & $\begin{array}{c}\geq 90 \text { yrs } \\
(n=155) \\
\%\end{array}$ & \\
\hline 1. Wheeze in past 12 months & 10.3 & 6.2 & 5.5 & 6.4 & 7.7 & 4.5 & 7.5 \\
\hline 2. Morning chest tightness in past 12 months & 4.0 & 4.8 & 3.6 & 4.0 & 5.7 & 1.9 & 4.2 \\
\hline $\begin{array}{l}\text { 3. Breathless at rest during the day in past } \\
12 \text { months }\end{array}$ & 4.7 & 5.8 & 6.4 & 4.9 & 6.4 & 3.9 & 5.2 \\
\hline 4. Nocturnal breathlessness in past 12 months & 3.5 & 4.1 & 2.7 & 4.0 & 4.0 & 1.9 & 3.6 \\
\hline 5. Morning phlegm & 29.7 & 34.9 & 39.1 & 17.7 & 22.4 & 20.0 & 25.7 \\
\hline $\begin{array}{l}\text { 6. Cough up phlegm } 3 \text { consecutive months } \\
\text { for } 2 \text { yrs }\end{array}$ & 14.1 & 13.4 & 11.8 & 6.6 & 6.0 & 6.7 & 10.0 \\
\hline $\begin{array}{l}\text { 7. Breathlessness on exposure to animals, dust } \\
\text { or feathers }\end{array}$ & 5.2 & 4.1 & 2.7 & 3.8 & 2.3 & 0.6 & 1.7 \\
\hline $\begin{array}{l}\text { 8. Chest tightness on exposure to animals, dust } \\
\text { or feathers }\end{array}$ & 2.9 & 1.4 & 0 & 1.9 & 1.0 & 0 & 3.8 \\
\hline 9. Breathlessness on exposure to cold air & 2.4 & 2.1 & 0.9 & 0.7 & 2.0 & 0.6 & 1.6 \\
\hline 10. Wheeze on exposure to cold air & 0.5 & 0.3 & 0 & 0.2 & 0.3 & 0.6 & 0.4 \\
\hline 11. Cough on exposure to cold air & 3.4 & 3.1 & 3.6 & 2.8 & 3.7 & 3.9 & 3.3 \\
\hline $\begin{array}{l}\text { 12. Breathlessness on exposure to household } \\
\text { chemicals }\end{array}$ & 3.9 & 2.7 & 0.9 & 2.3 & 0.7 & 0 & 2.3 \\
\hline 13. Wheeze on exposure to household chemicals & 0.7 & $\mathbf{0}$ & 0 & 0 & 0.7 & 0 & 0.3 \\
\hline 14. Cough on exposure to household chemicals & 4.2 & 3.1 & 1.8 & 3.3 & 1.7 & 0.6 & 3.0 \\
\hline 15. Breathlessness on exposure to traffic fumes & 6.2 & 1.7 & 1.8 & 3.1 & 2.0 & 0.6 & 3.4 \\
\hline 16. Wheeze on exposure to traffic fumes & 0.3 & 0 & 0 & 0 & 0.3 & 0 & 0.2 \\
\hline 17. Cough on exposure to traffic fumes & 5.9 & 3.8 & 0 & 5.9 & 2.7 & 1.3 & 4.4 \\
\hline 18. Breathlessness on exposure to smoke & 4.7 & 2.1 & 0.9 & 1.4 & 2.7 & 0 & 2.5 \\
\hline 19. Wheeze on exposure to smoke & 0.2 & 0 & 0 & 0.5 & 0.3 & 0 & 0.3 \\
\hline 20. Cough on exposure to smoke & 6.6 & 4.8 & 1.8 & 7.8 & 5.0 & 4.5 & 6.1 \\
\hline 21. Pulmonary tuberculosis & 6.7 & 3.8 & 8.2 & 0.2 & 1.0 & 0.6 & 3.2 \\
\hline 22. Asthma & 6.1 & 6.5 & 5.5 & 4.0 & 5.4 & 2.6 & 5.1 \\
\hline 23. Chronic bronchitis & 9.4 & 9.2 & 5.5 & 4.7 & 6.0 & 1.9 & 6.8 \\
\hline 24. Emphysema & 3.7 & 2.1 & 4.5 & 1.7 & 0.7 & 2.6 & 2.4 \\
\hline
\end{tabular}

*: subjects were asked "have you had the symptom, at any time in the last 12 months?" 
occupation. Housewives were asked about their husband's last full-time occupation. In 195 subjects, venous blood was drawn for determining total serum immuno-globulin $\mathrm{E}$ (IgE) concentration by an enzyme-linked immunosorbent assay (ELISA) technique.

Smoking habits were classified into: 1) nonsmokers, i.e. those who had never smoked; 2) ex-smokers, i.e. those who had stopped smoking for at least 12 months prior to the survey; and 3) current smokers, i.e. those who still smoked within the 12 months prior to the survey. Social class was classified according to the last full-time occupation of the subject or, in the case of a housewife, that of the husband. Eighteen subjects had no entry for last fulltime occupation; their social class was, therefore, unclassified and their data were not included for analysis of risk factors. Nonmanual workers were white collar workers; skilled manual workers were those in sales or service industries; and unskilled/semi-skilled manual workers were the blue-collar workers.

Results were analysed using and IBM mainframe computer, by the Statistical Package for Social Sciences, the Statistical Analysis System, and the BMDP programme. Risk factors for symptoms and diseases were examined by the step-wise multiple logistic regression method. MannWhitney tests were used for analysis of the total serum IgE data.

\section{Results}

Population data of the 2,032 subjects are shown in table 1. Information on smoking history and last occupation was obtained in 2,020 (99.9\%) and 2,014 (99.6\%) subjects, respectively. There were 1,065 lifelong nonsmokers constituting 53\% of those who answered the question on smoking habits. More males than females were ex-smokers (45 vs 18\%) and current smokers (25 vs $8 \%)$. The majority of subjects or their husbands were manual workers $(78 \%)$.

One thousand one hundred and twenty eight subjects (56\%) reported at least one respiratory symptom. The most frequent symptoms were morning phlegm (26\%), chronic cough with phlegm (10\%) and wheeze at some time in the past 12 months (7.5\%) (table 2). Of the 1,988 subjects who answered questions relating to symptoms developed on exposure to common aeroallergens or irritants (symptoms 7-20, table 2), 304 (15\%) reported positively to having at least one symptom. The least frequent complaints were wheeze on exposure to traffic fumes $(0.2 \%)$, wheeze on exposure to smoke $(0.3 \%)$, wheeze on exposure to household chemicals $(0.3 \%)$, and cough on exposure to cold air $(0.4 \%)$.

All but one subject answered the question "have you had any of the following conditions: pulmonary tuberculosis, asthma, chronic bronchitis or emphysema?". Table 2 (questions 21-24) shows the prevalence of these self-reported diseases. Eight percent of the respondents had either chronic bronchitis or emphysema. The prevalence of obstructive airway diseases was higher in males, of whom $10.7 \%$ had either chronic bronchitis or emphysema and $6.1 \%$ had asthma, against corresponding values of $5.5 \%$ and $4.3 \%$ in females, although these

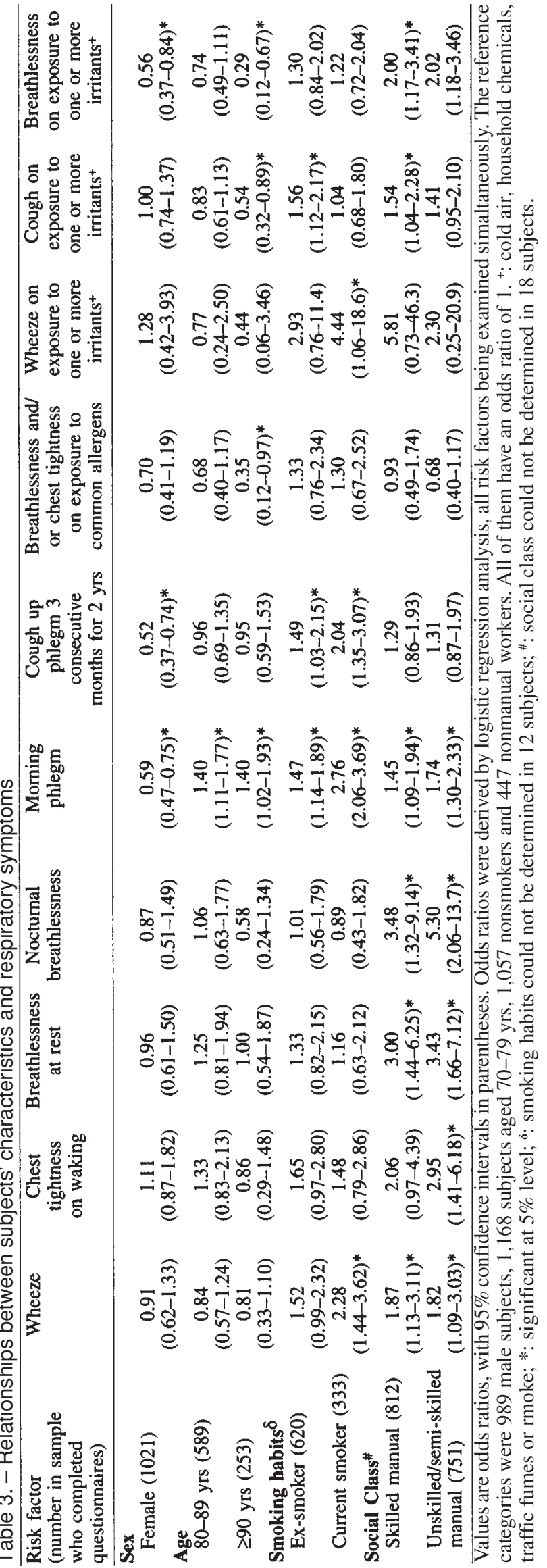


Table 4. - Relationships between subjects' characteristics and self-reported diseases

\begin{tabular}{|c|c|c|c|c|}
\hline $\begin{array}{l}\text { Subjects' characteristics } \\
\text { (number who completed } \\
\text { questionnaire) }\end{array}$ & Tuberculosis & Asthma & Chronic bronchitis & Emphysema \\
\hline \multicolumn{5}{|l|}{ Sex } \\
\hline Female (1020) & $0.07(0.03-0.19)^{*}$ & $0.71(0.45-1.11)$ & $0.68(0.45-1.02)$ & $0.64(0.33-1.26)$ \\
\hline \multicolumn{5}{|l|}{ Age } \\
\hline $80-89$ yrs $(588)$ & $0.68(0.36-1.27)$ & $1.15(0.75-1.78)$ & $1.13(0.77-1.65)$ & $0.49(0.22-1.07)$ \\
\hline$\geq 90$ yrs $(253)$ & $1.39(0.67-2.87)$ & $0.75(0.38-1.51)$ & $0.52(0.25-1.05)$ & $1.40(0.65-3.02)$ \\
\hline \multicolumn{5}{|l|}{ Smoking habits } \\
\hline Ex-smoker $(620)$ & $1.02(0.57-1.83)$ & $1.62(1.01-2.62)^{*}$ & $2.15(1.38-3.37)^{*}$ & $3.25(1.53-6.91)^{*}$ \\
\hline Current smoker (333) & $0.79(0.38-1.84)$ & $1.08(0.58-2.02)$ & $2.62(1.59-4.33)^{*}$ & $2.30(0.94-5.62)$ \\
\hline \multicolumn{5}{|l|}{ Social class } \\
\hline Skilled manual (812) & $0.82(0.44-1.54)$ & $2.12(1.12-4.03)^{*}$ & $1.73(1.03-2.89)^{*}$ & $2.00(0.78-5.14)$ \\
\hline Unskilled/semi-skilled manual (750) & $0.90(0.48-1.70)$ & $2.47(1.30-4.66)^{*}$ & $1.71(1.02-2.87)^{*}$ & $2.61(1.04-6.54)^{*}$ \\
\hline
\end{tabular}

Values are odds ratios, with $95 \%$ confidence intervals in parentheses. Odds ratios were derived by logistic regression analysis, all risk factors being examined simaltaneously. The reference categories are 989 male subjects, 1,168 subjects, aged 70-79 yrs, 1,057 nonsmokers and 447 nonmanual workers. All of them haven an odds ration of 1 . *: significant at $5 \%$ level.

differences did not reach statistical significance. A total of 218 subjects reported having at least one form of obstructive airway diseases, of whom 128 (59\%) consulted a doctor about their chest complaints in the past 12 months.

Data on smoking habits and social class were simultaneously examined in 2,010 subjects for analysis of relationships with respiratory symptoms (table 3) and in 2,009 subjects for analysis of relationships with past history of respiratory diseases (table 4). Women reported significantly less symptoms of morning phlegm, chronic cough with phlegm and breathlessness on exposure to irritants, as well as significantly lower prevalence of past tuberculosis $(0.55$ vs $3.8 \%$; $\mathrm{p}<0.05)$. In general, age had little impact on respiratory symptoms or diseases. However, the frequency of having morning phlegm increased with age, Vwhereas breathlessness or cough on exposure to irritants and allergens was less in those aged 90 yrs or more. Smoking was associated with a number of respiratory symptoms, including wheeze, morning phlegm, chronic cough with phlegm, wheeze and cough on exposure to irritants, and a history of chronic obstructive airway discase. Ex-smokers had significantly higher risks of asthma, emphysema and cough on exposure to one or more environmental irritants than current smokers, whilst the latter were more at risk of having chronic bronchitis, wheeze, phlegm and wheeze on exposure to one or more irritants. Social class was found to be significantly associated with most of the respiratory symptoms and diseases, with manual workers at higher risks than nonmanual workers.

The 195 subjects with total serum IgE measured had similar characteristics - age and sex distribution, social class, smoking habits and the prevalence of respiratory symptoms - as the total population (data not shown). Of these subjects, those with morning phlegm and chronic cough with phlegm had significantly higher level of this immunoglobulin than those without these symptoms (table 5). Although there was a trend for higher IgE levels in subjects with respiratory symptoms and past history of respiratory diseases, none of these comparisons reached statistical significance. Current smokers $(n=35)$ had significantly higher total serum $\operatorname{IgE}\left(158 \mathrm{IU} \cdot \mathrm{mL}^{-1}\right)$ than nonsmokers (39.8 IU $\left.\cdot \mathrm{mL}^{-1}, \mathrm{n}=105 ; \mathrm{p}=0.0003\right)$. The level in ex-smokers $\left(73.8 \mathrm{IU} \cdot \mathrm{mL}^{-1}, \mathrm{n}=55\right)$ was not significantly different from the current or nonsmokers.

Table 5. - Total serum IgE in subjects with and without respiratory symptoms and past history of respiratory diseases

\begin{tabular}{|c|c|c|}
\hline \multirow[b]{2}{*}{ Symptoms/diseases } & \multicolumn{2}{|c|}{ Median IgE IU $\cdot \mathrm{mL}^{-1}$} \\
\hline & $\begin{array}{l}\text { With } \\
\text { symptom/ } \\
\text { disease }\end{array}$ & $\begin{array}{l}\text { Without } \\
\text { symptom } \\
\text { disease }\end{array}$ \\
\hline Wheeze & 106 & 51.4 \\
\hline Chest tightness on waking & 100.3 & 51.6 \\
\hline Breathlessness at rest & 82.8 & 51.9 \\
\hline Noctumal breathlessness & 109 & 51.4 \\
\hline Morning phlegm & $109 *$ & 49.4 \\
\hline $\begin{array}{l}\text { Cough up phlegm } 3 \text { consecutive } \\
\text { months for } 2 \text { yrs }\end{array}$ & $107.5^{*}$ & 50.6 \\
\hline $\begin{array}{l}\text { Breathlessness and/or tightness } \\
\text { on exposure to common allergens }\end{array}$ & 148 & 51.5 \\
\hline Wheeze on exposure to $\geq 1$ irritants $^{+}$ & 148 & 51.5 \\
\hline Cough on exposure to $\geq 1$ irritants $^{+}$ & 85.9 & 51.6 \\
\hline Breathlessness on exposure to $\geq 1$ irritants ${ }^{+}$ & $s^{+} 127.5$ & 51.4 \\
\hline $\begin{array}{l}\text { Breathlessness and/or chest tightness } \\
\text { on exposure to common allergens }\end{array}$ & 148 & 51.5 \\
\hline Wheeze on exposure to $\geq 1$ irritants $^{+}$ & 148 & 51.5 \\
\hline Cough on exposure to $\geq 1$ irritants $^{+}$ & 85.9 & 51.6 \\
\hline Breathlessness on exposure to $\geq 1$ irritants $^{+}$ & $s^{+} 127.5$ & 51.4 \\
\hline Tuberculosis & 63.6 & 51.6 \\
\hline Asthma & 82.8 & 51.9 \\
\hline Chronic bronchitis & 98.4 & 51.5 \\
\hline Emphysema & 110 & 51.5 \\
\hline
\end{tabular}

*: $\mathrm{p}<0.05$ when compared with corresponding values in those without the symptoms; ${ }^{+}$: cold air, household chemicals, traffic fumes or smoke. 
Table 6. - Comparison of smoking habits, prevalence of respiratory symptoms and respiratory diseases between Hong Kong, southern England and northern Sweden

\begin{tabular}{|c|c|c|c|c|c|}
\hline \multirow[t]{2}{*}{ Symptoms/disease } & \multirow{2}{*}{$\begin{array}{c}\text { H.K. } \\
(n=2032)\end{array}$} & \multicolumn{2}{|c|}{ Southern England* } & \multirow{2}{*}{$\begin{array}{l}\text { Northern Sweden" } \\
\qquad 5](n=1542)\end{array}$} & \multirow{2}{*}{$\begin{array}{l}\text { USA* (CHS) } \\
{[6](n=5201)}\end{array}$} \\
\hline & & $\begin{array}{l}\text { Southampton } \\
{[3](n=2161)}\end{array}$ & $\begin{array}{l}\text { New Forest } \\
{[4](n=2011)}\end{array}$ & & \\
\hline Wheezing & 7.5 & 28.4 & 24.2 & 16.4 & 7.7 \\
\hline Breathless at rest & 5.2 & 20.6 & NA & NA & $\begin{array}{l}10.1 \\
\text { (grade 3) }\end{array}$ \\
\hline Nocturnal breathlessness & 3.6 & 9.5 & NA & NA & NA \\
\hline Chronic cough & 10.0 & NA & NA & 10.8 & 9.2 \\
\hline Sputum production & 25.7 & 21.6 & NA & 26.1 & 13.1 \\
\hline $\begin{array}{l}\text { Cough/wheeze/breathlessness on exposure } \\
\text { to allergens and respiratory irritants }\end{array}$ & 15.3 & 27.7 & 27.2 & NA & NA \\
\hline One or more symptoms & 55.5 & 58.4 & 60.0 & 43.9 & NA \\
\hline Chronic bronchitis & 6.8 & NA & 16.4 & 6.7 & 5.4 \\
\hline Asthma & 5.1 & 9.6 & 8.4 & 7.2 & 6.0 \\
\hline Lifetime nonsmoker & 52.7 & 39.7 & 42.4 & 51.7 & 46.1 \\
\hline Ex-smoker & 30.8 & 42.8 & 43.3 & 28.5 & 41.9 \\
\hline Current smoker & 16.5 & 17.5 & 14.3 & 19.8 & 12.0 \\
\hline
\end{tabular}

Values are percentages. *: subjects aged $\geq 65$ yrs; "* subjects aged $65-66$ yrs. CHS: Cardiovascular Health Study; NA: data not available.

\section{Discussion}

In this survey, we have shown that respiratory symptoms and diseases are common among elderly people in Hong Kong. About 55\% of this population have at least one respiratory symptom, over $10 \%$ have a history of either chronic bronchitis, emphysema or asthma and 3.2\% a history of pulmonary tuberculosis. In general, smoking history and social class are more important determinants of respiratory symptoms and diseases than either sex or age. As far as we are aware, this is the first survey specifically designed to study the prevalence of respiratory diseases in Chinese elderly and it shows comparable data with previous studies in Caucasians [3-6].

In this study, a stratified sampling method was used so that enough subjects of each sex in the oldest groups would be surveyed to provide information on respiratory health. Otherwise, a random survey of elderly aged over 70 yrs may not include enough subjects in the $\geq 80$ and $\geq 90$ yrs age groups. There are limitations to performing random population health surveys in Hong Kong, since there is no organized primary health-care system with a list of registered patients, and details collected for the population census could not be made available for this type of study. However, for those over 70 yrs of age, the Social Welfare Department does have a list of recipients of allowances which covers $90 \%$ or more of the elderly population, so that the population from which the sample was drawn may be considered representative of the Hong Kong Chinese elderly. A total of 3,400 invitation letters were sent via the Social Welfare Department and 2,032 subjects consented to and subsequently participated in this survey. There could be a bias in the sample eventually interviewed, since in Hong Kong the laws of confidentiality require that written consent be given by letter before the subjects could be interviewed. Because of this, we were also unable to determine the reasons for nonresponse or the characteristics of these people as we were not permitted to approach them directly. It is possible that nonresponders might be in poorer health which precluded their participation [7] and, therefore, our data might have underestimated the prevalence of respiratory symptoms and diseases in Hong Kong. On the other hand, it is equally possible that the nonresponders might be enjoying better health so that they would not be bothered to take part in the health survey [8], and hence our prevalence data might be overestimates. Although our response rate of $60 \%$ was not as high as that of similar studies in England and Sweden [35], it was similar to that of the United States [6]. Our sampling method was, and still is, the only feasible way to access information of this kind in large scale population surveys in our territory. We believe our data are the best possible estimates of the respiratory health of our elderly citizens.

The proportion of our subjects having at least one respiratory symptom $(56 \%)$ is similar to those seen in Southern England (58-60\%) but is more than that reported in Northern Sweden (44\%) (table 6). A valid comparison is possible between our data and those of Dow et al. [3], as our questionnaire was translated from theirs. The translation procedure involved an independent person who was bilingual and familiar with the territory to translate the original questionnaire into Chinese. This was then backtranslated into English by another person. The translated questionnaire was tested out in a group of elderly subjects and necessary modifications made before the survey was carried out. Our cohort had far fewer symptoms of wheezing, breathlessness at rest, nocturnal breathlessness, chronic cough or allergen/irritant-induced symptoms than the elderly in southern England, although sputum production was more common (table 6). The observation that a similar percentage of subjects had at least one symptom but individual symptoms were less common in Chinese suggests that these symptoms might be less severe in our subjects. Alternatively, perception of the individual symptoms might differ between the different ethnic groups.

Difference in questionnaires renders data comparison with those from Sweden and the USA more difficult 
but it appears that the prevalences of wheezing and chronic cough are similar and, again, sputum production was more frequently reported by our cohort. Cultural differences may be responsible for our higher reporting rate as coughing up phlegm or even spitting is more socially acceptable in Chinese, particularly those of the older generation. It is unlikely that smoking habits can account for our subjects' higher sputum production as we have a higher proportion of lifetime nonsmokers in our cohort than the other studies, especially those in southern England (table 6).

Although $10 \%$ of the participants admitted to having chronic productive cough for three consecutive months for 2 yrs, only $6.8 \%$ had a diagnostic label of chronic bronchitis. This underdiagnosis can also be seen in the Swedish and American studies, where the respective rates for chronic cough were $10.8 \%$ and $9.2 \%$ but the respective prevalences for chronic bronchitis were only $6.7 \%$ and $5.4 \%$ (table 6). Whether there is a similar underdiagnosis for asthma in our subjects cannot be determined from the questionnaire. However the lifetime prevalence of $5.1 \%$ is similar to that reported in young adults $(4.8 \%)$ but less than that of children (7.2-8\%) in Hong Kong [911]. Comparison with data from western countries showed that our elderly had the lowest prevalence of asthma (table 6).

Malnutrition during the intrauterine period and repeated respiratory infections in childhood have been implicated as causing more morbidity and mortality from chronic obstructive airways disease in later life [12]. It is unlikely that these are the reasons for the differences in data between our cohorts and Causcian elderly, as Hong Kong and mainland China, where many of our elderly emigrated from, were, and still are for China, much less affluent than the western countries in the early part of this century. Smoking, the most important environmental determinant of lung growth and decline in lung function [13], may account for the much higher prevalence of obstructive airway diseases and respiratory symptoms in the English elderly (table 6). That these diseases can cause considerable morbidity in our elderly was reflected by the fact that almost $60 \%$ of subjects with these diagnostic labels had sought medical advice for their illnesses during the preceding 12 months. Although the prevalence of tuberculosis has been gradually declining in Hong Kong, with annual notification rates of over 400 per 100,000 in the 1950 s decreasing to 112.4 per 100,000 in 1992 , the disease is still very common with a prevalence more than 10 times those reported in the USA England and Wales $[14,15]$. In our cohorts, $3.2 \%$ had a past history of pulmonary tuberculosis and this may predispose them to reactivation of the disease, which is a common occurrence in our locality as $16 \%$ of all notified cases in 1992 were patients aged 70 yrs or more.

Like other studies [3-6], we found smoking was an important determinant of respiratory symptoms and diseases (tables 3 and 4). Smoking was significantly associated with wheeze, morning phlegm, chronic cough, wheeze or cough on exposure to environmental irritants and chronic obstructive airways disease. Interestingly, although current smokers had a higher risk of having respiratory symptoms than the ex-smokers, they had a lower risk of having diagnostic labels of asthma, chronic bronchitis or emphysema than the latter. This could be because the reason for our ex-smokers to quit smoking was that they have been diagnosed as having a respiratory illness. Whether this was consequent to their doctors' advice or the fear of the disease is not known. However, it has previously been shown that physicians' advice could contribute to smoking cessation [16]. Another possibility for the seemingly lower prevalence of obstructive airway disease in current smokers is that they have not sought medical advice for their respiratory symptoms and, therefore, still continued to smoke and were not aware of their illness.

In our cohorts, manual workers or their wives had significantly higher risks of having wheeze, chest tightness on waking, breathlessness at rest and at night, morning phlegm, breathlessness or cough on exposure to environmental irritants (tables 3 and 4). A combination of possible occupational exposure, crowded living, poor housing and inadequate health care particularly during infancy, may all contribute. Although some investigators have also incriminated socioeconomic factors as being important for respiratory ailments [3, 17], others have not been able to confirm this relationship [6].

Sex was not an important factor for respiratory symptoms or diseases, except that females had significantly less complaints of morning phlegm, chronic cough or breathlessness on exposure to irritants. This could be due to under-reporting, as women might find phlegm and chronic cough socially less acceptable. We have failed to observe the influence of age on the prevalence of symptoms or diseases other than for morning phlegm. However, this apparent lack of effect could be because only those who were healthy lived to a more advanced age. As shown in table 3, those aged 90 yrs or over had, in fact, lower risks of having chest symptoms on exposure to common allergens and environmental irritants.

Atopy has been recognized as an associated feature of asthma [18] and bronchial hyperresponsiveness [19, 20]. Furthermore, it has also been reported that asthma at any age is accompanied by higher levels of total serum $\operatorname{IgE}$ and skin test reactivity [21]. However, others have been unable to show any relationship between asthma and skin test reactivity in nonsmokers [22]. Our data show that although there is a trend for higher serum IgE levels in subjects with respiratory symptoms or past history of respiratory diseases, only those in subjects with morning phlegm and chronic cough and phlegm were significantly different from those without these symptoms. Further analysis revealed that $\mathrm{IgE}$ levels were significantly higher in current smokers, a finding similar to that of other investigators [23-28]. Thus, IgE may just be a confounding factor for the chronic bronchitic symptoms in our subjects. However, a previous report suggested that it might have a synergistic effect with smoking in causing respiratory impairment [28], although this effect is not confirmed in our subgroup of 195 subjects with IgE measured (data not shown). 
In conclusion, respiratory symptoms and obstructive airway diseases are common in the Hong Kong elderly. Important risk factors include smoking and a lower socioeconomic class. Further studies to identify how many of such sufferers have a potentially reversible disease, such as asthma, will be useful to improve the quality of life of our elderly.

Acknowledgements: The authors would like to thank L. Dow for supplying the questionnaire, M Tong, K.Y. Yeung, W. Cheung and E. Wong for their technical assistance.

\section{References}

1. Williamson J, Stokoe IH, Gray S, et al. Old people at home: their unreported needs. Lancet 1964; i: 1117-1120.

2. Burrows B, Barbee RA, Cline MG, Knudson RJ, Lebowitz MD. Characteristics of asthma among elderly adults in a sample of the general population. Chest 1991; 100: 935-942

3. Dow L, Coggan D, Osmond C, Holgate ST. A population survey of respiratory symptoms in the elderly. Eur Respir $J$ 1991; 4: 267-272.

4. Horsley JR, Sterling IJN, Waters WE, Howell JBL. Respiratory symptoms among elderly people in the New Forest Area as assessed by postal questionnaire. Age Ageing 1991; 20: 325-331.

5. Lundbäck B, Nyström L, Rosenhall L, Stjernberg N. Obstructive lung disease in northern Sweden: respiratory symptoms assessed in a postal survey. Eur Respir $J$ 1991; 4: 257-266.

6. Enright PL, Kronmal RA, Higgins MW, Schenker MB, Haponik EF. Prevalence and correlates of respiratory symptoms and disease in the elderly. Chest 1994; 106: 827834.

7. Laukkanen P, Heikkinen E, Kauppinen M, Kallinen M. Use of drugs by noninstitutionalized urban Finns born in 1904-1923 and the association of drug use with mood and self-rated health. Age Ageing 1992; 21: 343-352.

8. Milne JS, Maule M, Williamson J. Method of sampling in a study of older people with a comparison of respondents and nonrespondents. Br J Prev Soc Med 1971; 25: 37-41.

9. Douglass C. Asthma, bronchial hyperreactivity and atopy in university students. M. Phil. Thesis, The Chinese University of Hong Kong, 1993.

10. Leung R, Tseng R. Allergic diseases in Hong Kong schoolchildren. Hong Kong Practioner 1993; 15: 2409-2420.

11. Ong SG, Lui J, Tam YC. Studies on respiratory health of primary school children in urban communities of Hong Kong. Sci Total Environ 1991; 106: 121-135.

12. Barker DJP, Godfrey KM, Fall C, Osmond C, Winter $\mathrm{PD}$, Shaheen SO. Relation of birth weight and childhood respiratory infection to adult lung function and death from chronic obstructive airways disease. $\mathrm{Br}$ Med $\mathrm{J}$ 1991; 303: 671-674.

13. Tager IB, Segal MR, Speizer FE, Weiss ST. The natural history of forced expiratory volumes: effect of cigarette smoking and respiratory symptoms. Am Rev Respir Dis 1988; 138: 837-849.

14. Schluger NW, Rom WN. Current approaches to the diagnosis of active pulmonary tuberculosis. Am J Respir Crit Care Med 1994; 149: 264-267.

15. Office of Population Censuses and Surveys. Communicable disease statistics. 1988. London, HMSO, 1990.

16. Research Committee of the British Thoracic Society. Smoking cessation in patients: two further studies by the British Thoracic Society. Thorax 1990; 45: 835-840.

17. Viegi G, Paoletti P, Prediletto R, et al. Prevalence of respiratory symptoms in an unpolluted area of northern Italy. Eur Respir J 1988; 1: 311-318.

18. Kalliel JN, Goldstein BM, Barman SS, Settipane GA. High frequency of atopic asthma in a pulmonary clinic population. Chest 1989; 96: 1336-1340.

19. Cockroft D, Murdock K, Berscheid B. Relationship between atopy and bronchial responsiveness to histamine in a random population. Ann Allergy 1984; 53: 26-29.

20. Cookson WOCM, Musk AW, Ryan G. Associations between asthma history, atopy and nonspecific bronchial responsiveness in young adults. Clin Allergy 1986; 16: 425-432.

21. Burrows B, Martinez FD, Halonen M, Barbee RA, Cline MG. Association of asthma with serum IgE levels and skin test reactivity to allergy. N Engl J Med 1989; 302: 271-277.

22. Gergen PJ, Turkeltaub PC. The association of allergy, skin test reactivity and respiratory disease among whites in the US population: data from the second National Health and Nutrition Examination Survey 1976 to 1980. Arch Intern Med 1991; 151: 487-492.

23. Gerrard JW, Helner DC, Ko CG, Mink J, Meyers A, Dosman JA. Immunoglobulin levels in smokers and nonsmokers. Ann Allergy 1980; 44: 261-262.

24. Burrows B, Halonen M, Barbee RA, Lebowitz MD. The relationship of serum immunoglobulin Eto cigarette smoking. Am Rev Respir Dis 1981; 124: 523-525.

25. Warren CPQ, Holford-Stevens WM, Wong C, Manfreda J. The relationship between smoking and total serum immunoglobulin E levels. J Allergy Clin Immunol 1982; 69: 370 375.

26. Bahna SI, Heiner DC, Myhre BA. Immunoglobulin E pattern in cigarette smokers. Allergy 1983; 38: 57-64.

27. Vollmer WM, Buist AS, Johnson LR, McCamant LE, Halonen M. Relationship between serum IgE and crosssectional and longitudinal FEV1 in two cohort studies Chest 1986; 90: 416-423.

28. Dow L, Coggan D, Campbell MJ, Osmond C, Holgate ST The interaction between immunoglobulin $\mathrm{E}$ and smoking in airflow obstruction in the elderly. Am Rev Respir Dis 1992; 146: 402-407. 